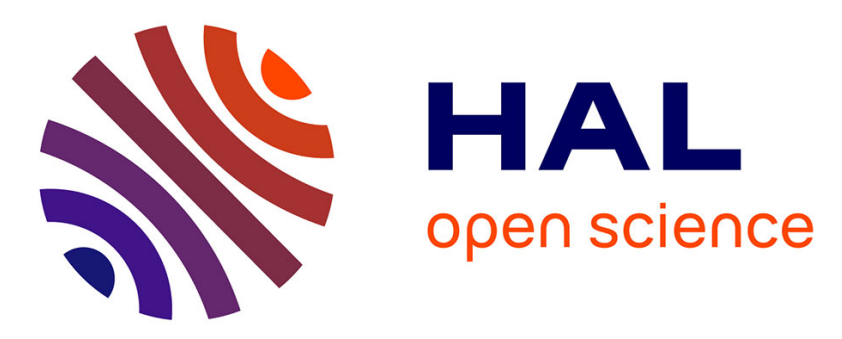

\title{
Proteins of seminal fluid and spermatozoa in the trout (Oncorhynchus mykiss): partial characterization and variations
}

Maurice Loir, Catherine Labbé, Gérard Maisse, A. Pinson, Geneviève Boulard, Brigitte Mourot, F. Chambeyron

\section{To cite this version:}

Maurice Loir, Catherine Labbé, Gérard Maisse, A. Pinson, Geneviève Boulard, et al.. Proteins of seminal fluid and spermatozoa in the trout (Oncorhynchus mykiss): partial characterization and variations. Fish Physiology and Biochemistry, 1990, 8, pp.485-495. 10.1007/BF00003405 . hal02713899

\section{HAL Id: hal-02713899 \\ https: / hal.inrae.fr/hal-02713899}

Submitted on 1 Jun 2020

HAL is a multi-disciplinary open access archive for the deposit and dissemination of scientific research documents, whether they are published or not. The documents may come from teaching and research institutions in France or abroad, or from public or private research centers.
L'archive ouverte pluridisciplinaire HAL, est destinée au dépôt et à la diffusion de documents scientifiques de niveau recherche, publiés ou non, émanant des établissements d'enseignement et de recherche français ou étrangers, des laboratoires publics ou privés. 


\title{
Proteins of seminal fluid and spermatozoa in the trout (Oncorhynchus mykiss): Partial characterization and variations
}

\author{
M. Loir, C. Labbé, G. Maisse, A. Pinson, G. Boulard, B. Mourot and F. Chambeyron \\ Physiologie des Poissons, INRA, Campus de Beaulieu, 35042 Rennes, France
}

Keywords: salmonid, sperm, seminal fluid, membrane, protein, electrophoresis, immunoblot, lipoprotein

\begin{abstract}
The protein composition of seminal fluid, blood serum, sperm plasma membrane and flagellum of rainbow trout were analysed by SDS-polyacrylamide gel electrophoresis. Immunological identity between proteins of the 2 fluids and sperm components was studied using crossed immunoelectrophoresis, rocket immunoelectrophoresis and immunoblotting. Results indicate that many seminal proteins are antigenically-related to serum proteins, proteins of sperm origin are present in seminal fluid in varying amounts, depending on the animals and sampling time, and several serum-like seminal proteins are bound to spermatozoa.

Lipoproteins were isolated from seminal fluid (mean level: $33 \mu \mathrm{g} / \mathrm{ml}$ ) and characterized. They were identified as being HDL-like lipoproteins. A possible physiological role is proposed for these seminal lipoproteins.
\end{abstract}

\section{Introduction}

In rainbow trout, spermatogenesis is completed about 2 months before spawning starts and spermatozoa are then in the lobular lumen. During the spawning period, spermatozoa are stored for variable periods in the sperm ducts. Although it has been shown in sea bass (Billard et al. 1977) that sperm fertility decreases throughout the reproductive period as a consequence of the sperm aging process, it has been demonstrated in trout that the capacity of sperm for withstanding cryopreservation and the resistance of the gamete plasma membrane to hypotonic shock are maintained, if not increased, during the spawning period (Malejeac et al. 1990). Thus, as already proposed by Billard (1976), the sperm duct which is the organ of sperm storage, most likely plays an important role in conservation of sperm fertility. However, when males are considered individually, unexplained apparently erratic varia- tions are observed in sperm quality and in the properties of the gamete membrane (Billard 1976, 1983; Maisse et al. 1988; Malejac et al. 1990).

In the lobular lumen and in the sperm duct, spermatozoa are suspended in seminal fluid which inhibits sperm motility and provides the components needed for sperm metabolism. The chemical composition of seminal fluid, which is different from that of blood plasma, is probably due to the existence of a blood-testis barrier (Steyn and van Vuren 1986). The seminal fluid of teleosts is a product of the testes (Clemens and Grant 1964) and of the sperm duct (Billard et al. 1971), the epithelium of which is secretory. The ionic composition of the seminal plasma has been established for several teleosts (Billard and Jalabert 1974; Plouidy and Billard 1982; Morisawa 1985; Piironen 1985; Steyn and van Vuren 1986). The concentration of various organic components such as total proteins, amino acids, total lipids, glucose, fructose, enzymes, has 
been determined in some fish species (Plouidy and Billard 1982; Billard and Menezo 1984; Piironen 1985; Steyn and van Vuren 1986). In particular, lipids were detected in salmon seminal fluid (Piironen 1985) and phospholipids and cholesterol were identified in seminal plasma of cyprinid species (Belova 1982; Plouidy and Billard 1982). The form in which these molecules are present is not known.

Although seminal fluid has a protective effect on the gametes (Billard 1983), little is known about its proteinaceous components and their physiological functions. Since sperm possess limited biosynthetic capabilities, it has been documented in mammals that interactions of the spermatozoa with the seminal fluid would play a major role in the surface membrane changes which accompany epididymal sperm maturation. Events similar to such a maturation do not seem to occur in the vas deferens of trout. Indeed, in normal males, sperm acquire the ability to fertilize in the testes before being transferred to the sperm duct (Billard 1976). However, it is unknown whether intermale differences in the fertilizing ability of sperm (using either fresh or cryopreserved milt) are related or not to the quantity and/or quality of the organic components of the seminal fluid.

In order to improve our knowledge of trout seminal plasma, we analysed the proteins of blood serum, seminal fluid and gametes and using immunological techniques, we tentatively determine which antigens are common to the 2 fluids and gametes, and we identified and characterized lipoproteins present in the seminal fluid.

\section{Materials and methods}

\section{Animals and sample preparation}

One to 3 year-old males of rainbow trout were used. They were kept at $12-15^{\circ} \mathrm{C}$, in recycled freshwater, under natural photoperiod.

Sperm was collected by hand stripping, taking care to avoid contamination by blood and feces, then stored on ice. Sperm samples were centrifuged $\left(500 \times \mathrm{g}\right.$ for $20 \mathrm{~min}$ at $4^{\circ} \mathrm{C}$, then $1000 \times \mathrm{g}$ for 10 min; these conditions affect neither sperm motility nor morphology) and the seminal fluid was collected. Spermatozoa were resuspended in seminal fluid mineral medium (SFMM, Billard and Jalabert 1974) $\mathrm{pH} 9$, then washed once or twice by centrifugation. Seminal fluid was centrifuged either at 1000 $\times \mathrm{g}$ for $20 \mathrm{~min}$ or at $100,000 \times \mathrm{g}$ for $40 \mathrm{~min}$ before being stored at $-30^{\circ} \mathrm{C}$ until needed. No differences was apparent between the 2 procedures.

Blood samples were collected from the caudal vein and serum was prepared in the classic way.

\section{Polyacrylamide gel electrophoresis}

SDS-polyacrylamide slab gel electrophoresis was carried out according to Laemmli (1970) on 6-16\% gradient gels. Samples of seminal fluid were diluted 1:2 with electrophoresis samples buffer containing $2 \%$ SDS and 5\% mercaptoethanol; $70 \mu \mathrm{l}$ was loaded onto the gels. Blood serum was diluted 1:10 with sample buffer and $10 \mu \mathrm{l}$ of this was loaded. Lipoprotein samples were diluted 3:4 with concentrated sample buffer $(\times 4)$ and $100 \mu$ l of this was loaded. Before loading, all samples were boiled for $5 \mathrm{~min}$. Pharmacia calibration kit proteins were used as molecular weight markers. Proteins were stained with $0.2 \%$ R250 Coomassie Blue. Gels were scanned in a Vernon PHI5 densitometer. In some cases, the relative amount of protein bands was estimated by integration of the area under the whole electrophoregram and that under the considered bands.

Polyacrylamide gel electrophoresis under nondenaturing conditions was carried out as above, excepted that SDS and mercaptoethanol were absent in all the solutions and that gels were preelectrophoresed for 4 hours.

\section{Preparation of antisera and immunological procedures}

Polyspecific antisera were raised in rabbits for serum proteins, for seminal fluid proteins and for saline-soluble spermatozoa proteins. Trout serum was diluted with $0.140 \mathrm{M} \mathrm{NaCl}$ to obtain $5 \mathrm{mg}$ protein $/ \mathrm{ml}$. Seminal fluid was concentrated to the same protein concentration by dialysis against 
$0.140 \mathrm{M} \mathrm{NaCl}$ under vacuum. Washed spermatozoa were homogenised in $0.140 \mathrm{M} \mathrm{NaCl}$ in $0.02 \mathrm{M}$ Tris $\mathrm{HCl}$ buffer $\mathrm{pH} 7.4$, then centrifuged at $1500 \times \mathrm{g}$ for $30 \mathrm{~min}$ and the supernatant was collected and adjusted to $5 \mathrm{mg}$ protein $/ \mathrm{ml}$. For every antigen, a mixture of $0.9 \mathrm{ml}$ of antigen solution and $0.9 \mathrm{ml}$ Freund's complete adjuvant ( 2 first injections) then incomplete adjuvant was injected intradermally into the abdomen of 2 rabbits, seven times biweekly. Antisera were tested by the Ouchterlony method and by rocket immunoelectrophoresis performed following routine procedures (Johnstone and Thorpe 1982).

Presence of immunologically-related antigens in blood serum and in seminal fluid on the one hand and in seminal fluid and in spermatozoa on the other was checked using crossed immunoelectrophoresis (Johnstone and Thorpe 1982) and immunoblotting procedure. Following slab gel electrophoresis, carried out with denaturing conditions either present or absent, proteins were transferred to nitrocellulose sheets (Gelman, $0.2 \mu \mathrm{m}$ ) by electrophoresis in the presence of $0.03 \%$ SDS and $20 \%$ methanol. Efficiency of transfer was checked by staining the transferred gel with Coomassie Blue and by staining the sheets with $0.2 \%$ Ponceau red in $3 \%$ trichloracetic acid before immunological detection. Antigens on the sheets were detected by indirect specific labelling performed at $37^{\circ} \mathrm{C}$. Unspecific binding was prevented by using swine serum diluted 1:10 (TBSS; $1 \mathrm{~h}$ incubation) in 0.02 $\mathrm{M}$ Tris $\mathrm{HCl}$ buffer $\mathrm{pH} 8,1 \% \mathrm{NaCl}$ (TBS). The specific immunserum was diluted 1:100 in TBSS (2 $h$ incubation). The second ligand was antisera to rabbit IgG raised in swine and conjugated with horseradish peroxidase (Dako) diluted 1:500 in TBSS ( $2 \mathrm{~h}$ incubation). After each incubation with the antisera, sheets were washed twice for $10 \mathrm{~min}$ with $0.05 \%$ Tween 20 in TBS. Peroxidase conjugates were detected by reaction with 4 chloro- $1 \alpha$ naphtol and hydrogen peroxide.

\section{Anion-exchange HPLC of proteins in blood serum and in seminal fluid}

The method used to fractionate proteins of the 2 biological fluids on a Mono $Q$ column $(5 \times 50 \mathrm{~mm}$ i.d., Pharmacia) was modified from Cheng et al. (1986). Briefly, we used, at room temperature, a chromatographic system from Waters equipped with an automated gradient controller and 2 pumps. Sample (pools of blood serum or seminal fluid collected at the same time from the same males) volume was $2 \mathrm{ml}$ and protein concentration was $10 \mathrm{mg} / \mathrm{ml}$ (seminal fluid was concentrated by vacuum dialysis). Protein elution was performed using a linear gradient 0 to $0.480 \mathrm{M} \mathrm{NaCl}$ in $0.02 \mathrm{M}$ Tris $\mathrm{HCl}$ buffer pH 7.4 with 3 steps at $0.78,0.120$ and $0.246 \mathrm{M} \mathrm{NaCl}$. The effluent was monitored by $\mathrm{UV}$ absorbance at $280 \mathrm{~nm}$. Seven milliliter fractions were collected, dialysed against $0.02 \mathrm{M}$ Tris $\mathrm{HCl}$ buffer pH 7.4 then analysed by SDS gel electrophoresis. Each experiment was repeated 3 times.

\section{Preparation of plasma membrane proteins}

Direct extraction with sodium desoxycholate: Spermatozoa were washed once more with SFMM then pellets were resuspended in 12 volumes $0.2 \% \mathrm{Na}$ desoxycholate in $0.25 \mathrm{M}$ sucrose, $0.001 \mathrm{M}$ phenylmethylsulfonide fluoride (PMSF), 0.005 M Hepes buffer pH 8.0 at $4^{\circ} \mathrm{C}$ for $45 \mathrm{~min}$ (Jones et al. 1983). Unlike boar sperm (Klint et al. 1985), the increase of desoxycholate concentration up to $0.6 \%$ or the addition of $0.001 \mathrm{M}$ dithiothreitol did not change the electrophoretic pattern of membrane proteins. After centrifugation $(1000 \times \mathrm{g}, 20 \mathrm{~min})$, supernatants were removed then centrifuged at $25,000 \times \mathrm{g}$ for $1 \mathrm{~h}$. Proteins were collected by centrifugation after precipitation by mixing overnight with 9 volumes of ethanol at $4^{\circ} \mathrm{C}$. Proteins were washed with ethanol, dried, then solubilised in electrophoresis sample buffer at a concentration of $1.5 \mathrm{mg} / \mathrm{ml}$.

Plasma membrane isolation using nitrogen cavitation: Membranes vesicles were prepared as follows: after washing, $4.8 \times 10^{11}$ spermatozoa were

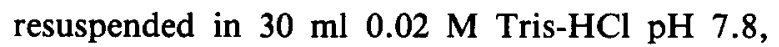
$0.003 \mathrm{M} \mathrm{MgCl}_{2}, 0.001 \mathrm{M}$ PMSF, $20 \mu \mathrm{g}$ Soybean trypsin inhibitor $/ \mathrm{ml}, 0.1 \mu \mathrm{g}$ pepstatine/ml (Tris$\mathrm{MgCl}_{2}$ ), containing $0.25 \mathrm{M}$ sucrose. Nitrogen cavitation was performed under 900 PSI for $20 \mathrm{~min}$. Nuclei and flagella were removed from the homogenate by centrifugation onto 0.65 volumes of $1 \mathrm{M}$ 


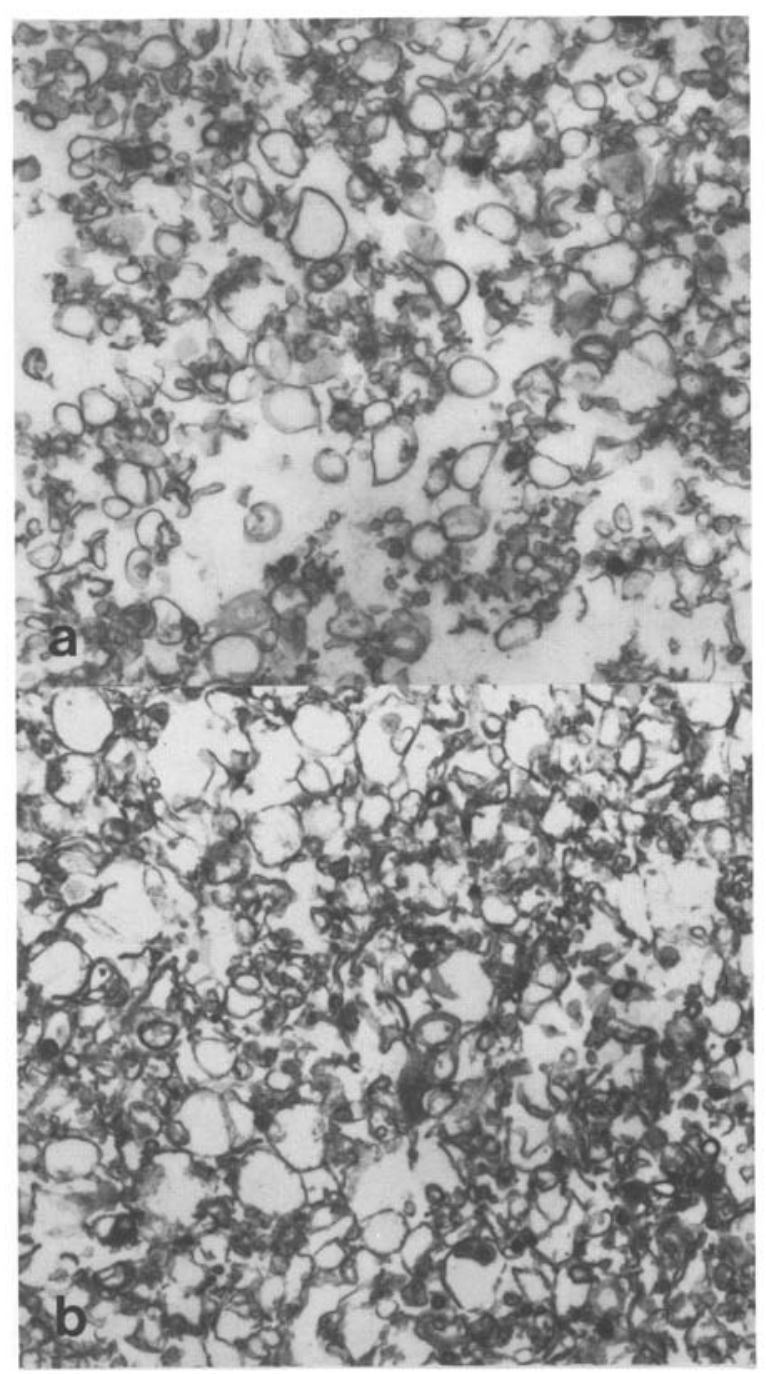

Fig. 1. Electron micrographs $(\times 8,200)$ of membrane pellets obtained after centrifugation on continuous sucrose gradients of the homogenate resulting from disruption of trout spermatozoa by nitrogen cavitation. a: band 1 material ( $0.25 \mathrm{M}$ sucrose); b: band 3 material ( $0.62 \mathrm{M}$ sucrose).

sucrose at $500 \times \mathrm{g}$ for $10 \mathrm{~min}$, then at $1500 \times \mathrm{g}$ for $10 \mathrm{~min}$. The suspension was then fractionated by centrifugation $\left(80,000 \times \mathrm{g}, 2 \mathrm{~h}\right.$ at $\left.4^{\circ} \mathrm{C}\right)$ on a continuous $0.25-1.8 \mathrm{M}$ sucrose gradient. Fractionated material was collected, diluted at least $1: 3$ in Tris$\mathrm{MgCl}_{2}$ and pelleted at $100,000 \times \mathrm{g}$ for $30 \mathrm{~min}$. As confirmed by electron microscopy (Fig. 1), by determination of lactic dehydrogenase and succinic dehydrogenase activities, of cholesterol, phospholipid and triglyceride, membrane vesicles were recovered without detectable contamination by other spermatozoa organelles in three bands $(0.25$, 0.37 and $0.62 \mathrm{M}$ sucrose).

\section{Preparation of flagellar proteins}

After treatment with sodium desoxycholate, the pellets of demembranated spermatozoa were resuspended in the desoxycholate solution then sonicated until nearly all the heads and flagella were disconnected. Nuclei were discarded by pelleting $(1,000 \times \mathrm{g}, 4 \mathrm{~min})$. The flagella suspension was adjusted to $0.9 \mathrm{M}$ sucrose then centrifuged $(100,000$ $\times \mathrm{g}, 3 \mathrm{~h}$ ) on a discontinuous $1.15-2.2 \mathrm{M}$ sucrose gradient. Completely demembranated flagella (control with electron microscopy) were collected at the interface $1.70-2.00 \mathrm{M}$ sucrose, diluted at least $1: 3$ in SFMM, 0.001 M PMSF and pelleted at $25,000 \times \mathrm{g}$ for $25 \mathrm{~min}$.

\section{Electron microscopy}

Aliquots of membrane and flagella suspensions were fixed in $4 \%$ glutaraldehyde in phosphate buffered saline (PBS) pH 7.5, washed in $0.2 \mathrm{M}$ cacodylate buffer pH 7.5 and post-fixed in 1\% osmium tetroxide in $0.1 \mathrm{M}$ cacodylate buffer plus $1 \%$ potassium ferricyanide. Material was embedded in $2 \%$ agar, dehydrated in acetone and embedded in Epon-araldite. Sections were double-stained and observed with a $100 \mathrm{CX}$ Jeol electron microscope.

\section{Isolation and analysis of seminal fluid lipoproteins}

Total lipoproteins were isolated from seminal fluid by flotation according to Fremont and Marion (1982) modified for seminal fluid lipoproteins. The density of seminal fluid was raised from $1.006 \mathrm{~g} / \mathrm{ml}$ $(1.0064 \pm 0.0012, \mathrm{n}=7)$ to $1.27 \mathrm{~g} / \mathrm{ml}$ by addition of solid $\mathrm{KBr}$. Preliminary experiments had shown that a very low proportion of the expected amount of lipoproteins was recovered when the density was adjusted to $1.21 \mathrm{~g} / \mathrm{ml}$, while most of the lipoproteins were obtained without increased contamina- 

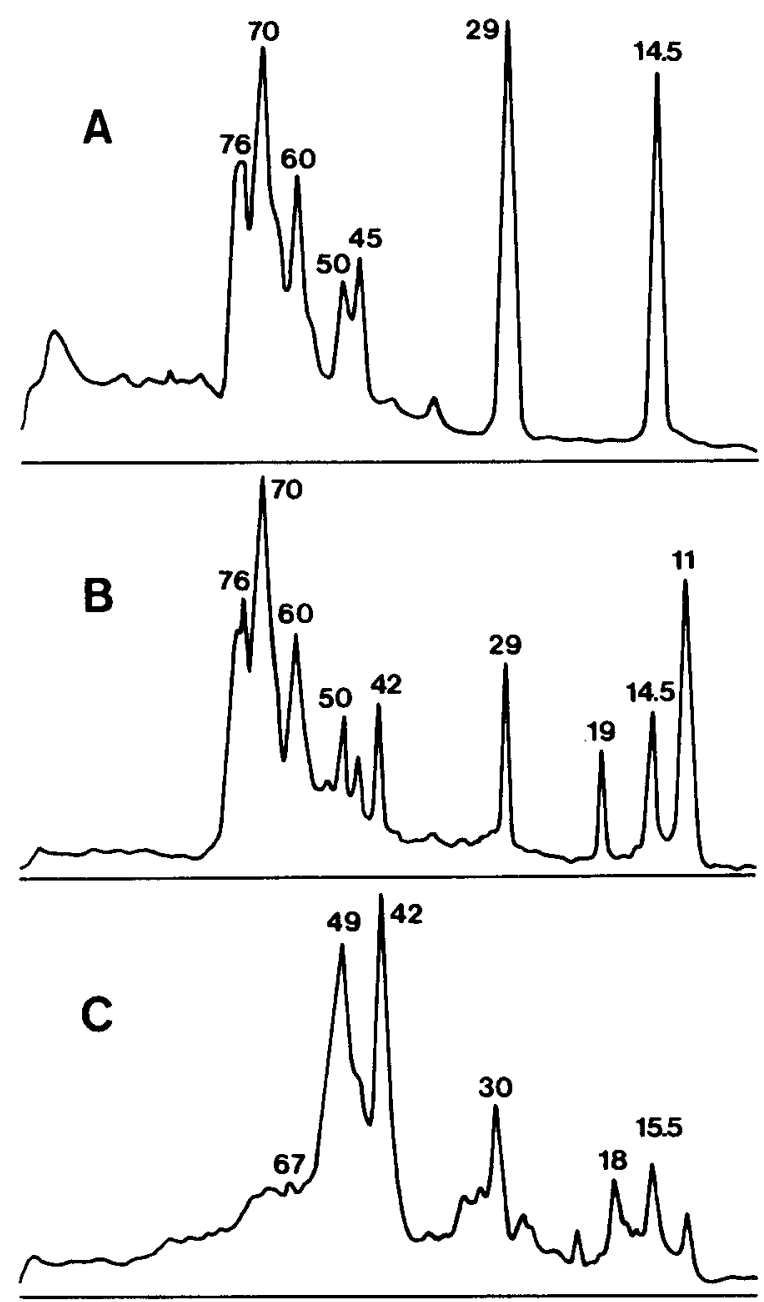

Fig. 2. Electrophoregrams (SDS gels) of the proteins present in the antigen solutions used to immunize the rabbits. A: blood serum; pool from males at the beginning of the spermiation period. B: Seminal fluid; pool from same males. C: salinesoluble sperm proteins; pool from same males.

tion by other proteins after adjustment to 1.27 $\mathrm{g} / \mathrm{ml}$. Polycarbonate tubes were filled with $22.5 \mathrm{ml}$ sample (containing $0.03 \mathrm{M} \mathrm{Na}$ azide and $0.001 \mathrm{M}$ PMSF), overlaid with $6.5 \mathrm{ml}$ saline solution at 1.27 $\mathrm{g} / \mathrm{ml}$. These were centrifuged at $143,000 \times \mathrm{g}$ for 44 $\mathrm{h}$ at $10^{\circ} \mathrm{C}$. Lipoproteins were collected from the top of the tubes. An aliquot was also collected from the bottom. All the samples were exhaustively dialysed against $0.185 \mathrm{M} \mathrm{NaCl}, 0.03 \mathrm{M} \mathrm{Na}$ azide and 0.001 M EDTA.

Total lipoproteins, LDL and HDL were isolated from 2 pools of blood serum obtained from mature males, according to Fremont and Marion (1982).

Polyacrylamide-gel electrophoresis of lipoproteins was performed in discontinuous three-step gradient gels $(2.8,3.4$ and $6.2 \%, \mathrm{pH} 8.9$; Leger et al. 1979) after prestaining the lipoproteins with Sudan black B.

\section{Other methods}

Protein was determined by the method of Lowry et al. (1951) using bovine serum albumin as the standard. Protein in lipoprotein samples was measured according to Fremont and Marion (1982), in the presence of $5 \% \mathrm{Na}$ desoxycholate. Enzymatic methods were used to quantify total cholesterol, triglyceride and phospholipid (Boehringer).

\section{Results}

Electrophoretic analysis of blood serum and seminal fluid proteins

Most of the proteins identified in blood serum by 1D SDS gel electrophoresis (Fig. 2) were present in roughly the same relative amounts whatever the sampling time during the spermiation period, while the relative amount of some of the others was slightly variable. Major protein bands were: 14.5 , $29,45,50,60,68-70,76$ and $78 \mathrm{KD}$. Some of the serum proteins co-migrated with apolipoproteins present in serum total lipoproteins (Fig. 3) and in serum HDL and LDL: 14.5 KD (apo. AII), $29 \mathrm{KD}$ (apo. AI), $44 \mathrm{KD}, 54 \mathrm{KD}, 76 \mathrm{KD}$ and $250 \mathrm{KD}$ (apo. B).

The mean protein concentration in seminal fluid, determined for 45 sperms collected throughout the spermiation period, was $1.737 \mathrm{mg} / \mathrm{ml} \pm 0.792$.

No protein was significantly detectable above 85 KD in seminal fluid (Figs. 2 and 3). Proteins from 45 to about $85 \mathrm{KD}$ and proteins 14.5 and $29 \mathrm{KD}$ comigrated with proteins present in serum and their amounts roughly paralleled those of the serum proteins. Various seminal proteins were usually present in variable relative amounts depending on the sampling time during the spermiation period. It was the case for four proteins $(11,19,37$ and $42 \mathrm{KD})$ un- 


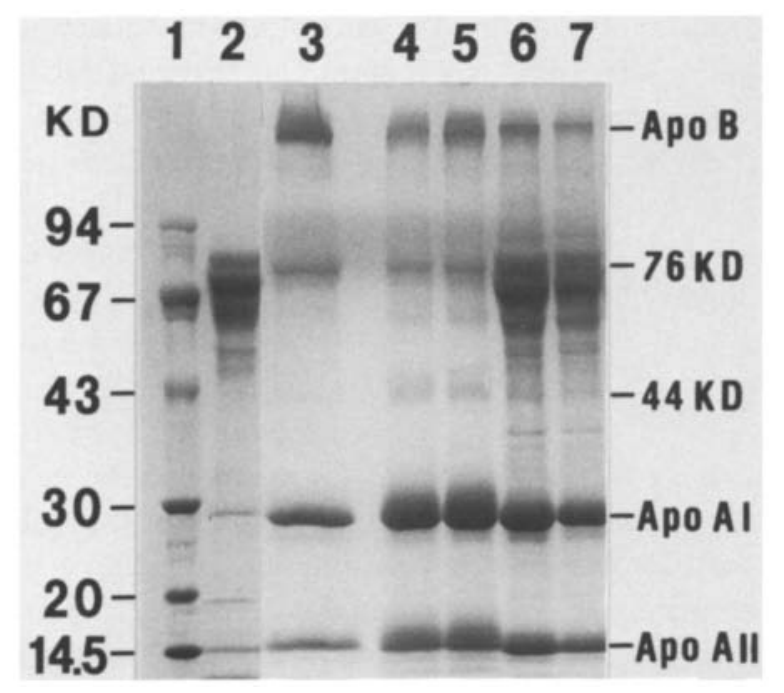

Fig. 3. Electrophoretic patterns of blood serum, seminal fluid and serum apolipoproteins, SDS polyacrylamide gel. 1: standard molecular weights. 2: pool of seminal fluid. 3, 4,5: serum total lipoproteins; pools of serum from males. 6,7 : blood serum; pools from males.

related to serum. Protein $42 \mathrm{KD}$ which co-migrated with the major membrane protein was in higher amounts at the beginning and especially at the end of the spermiation period (additional proteins comigrating with membrane proteins were also observed at this time), rather than in the middle of the period. The relative amounts of proteins 29 and 14.5 KD as percentage of total seminal proteins (estimated by integrative densitometry of the bands after analysis on SDS gels) were followed for at least 3 weeks for 10 males considered individually. It appeared that they varied slightly during this period but depended on the males.

Immunochemical identity between seminal proteins, serum proteins and sperm proteins

The antiserum specific for serum proteins was tested for antigenicity of seminal fluid, firstly using crossed immunoelectrophoresis. Six to 13 rockets were observed (Fig. 4). Secondly, we used the immunoblotting technique (Fig. 5). Seminal proteins $11,14.5,16.5,29,34,40,44-45$ and 50 to $80 \mathrm{KD}$ were regularly recognized by the antiserum for se-

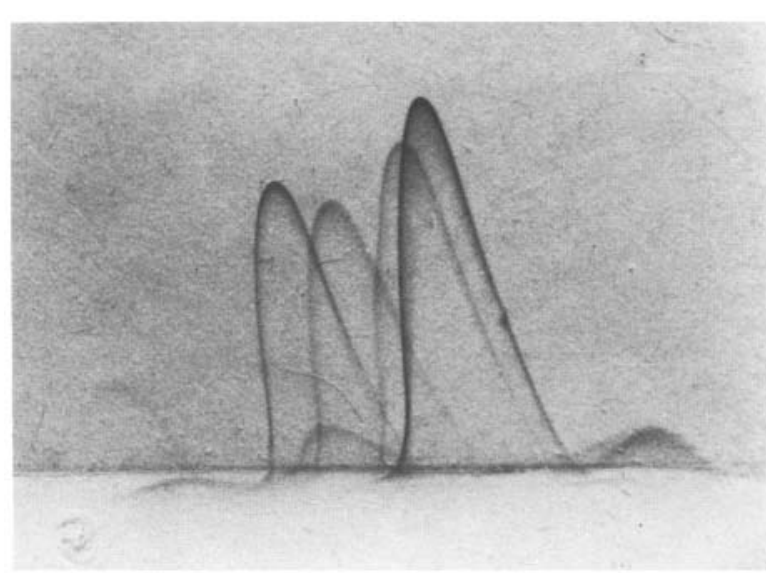

Fig. 4. Crossed immunoelectrophoresis of seminal proteins (pool of seminal fluid; males at beginning of spermiation; identical to pool 2 in Fig. 5). The second dimension contained antiserum specific for serum proteins.

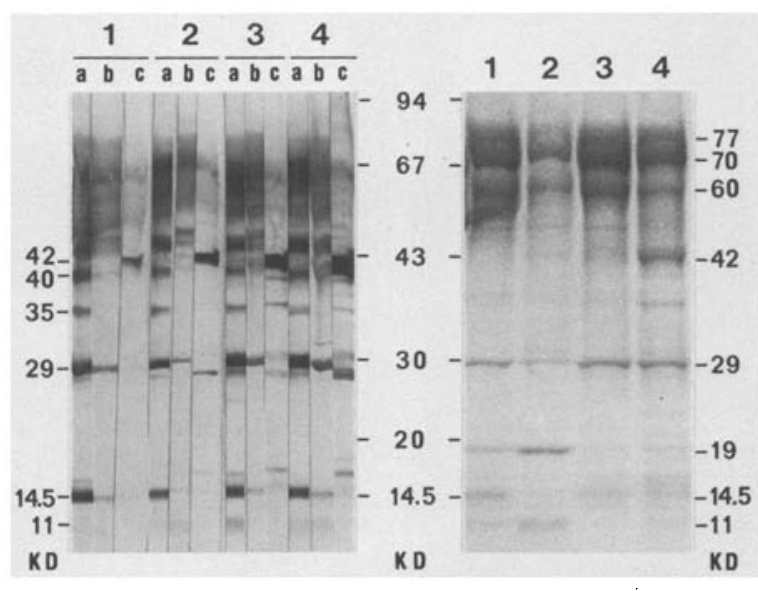

Fig. 5. Immunoblots (left) obtained after electrophoresis of 4 pools of seminal fluid on SDS gel and transfer to nitrocellulose sheet (right, after staining with Ponceau red). a: immunodetection with antiserum specific for serum proteins. $b$ : antiserum for seminal proteins. c: antiserum for $\mathrm{NaCl}$-soluble sperm proteins. Pool 1: males in mid-spermiation period. Pools 2 and 3: males at beginning of spermiation. Pool 4: males at the end of spermiation period; seminal fluid collected from testes.

rum proteins. When immunodetection was carried out after transfer of seminal fluid proteins from non-denaturing gels, identification of the protein bands by the molecular weight was not possible, but about as many bands were recognized by antiserum for serum proteins as after transfer from SDS gels.

Depending on the pools of seminal fluid which were checked by immunoblotting, variable num- 

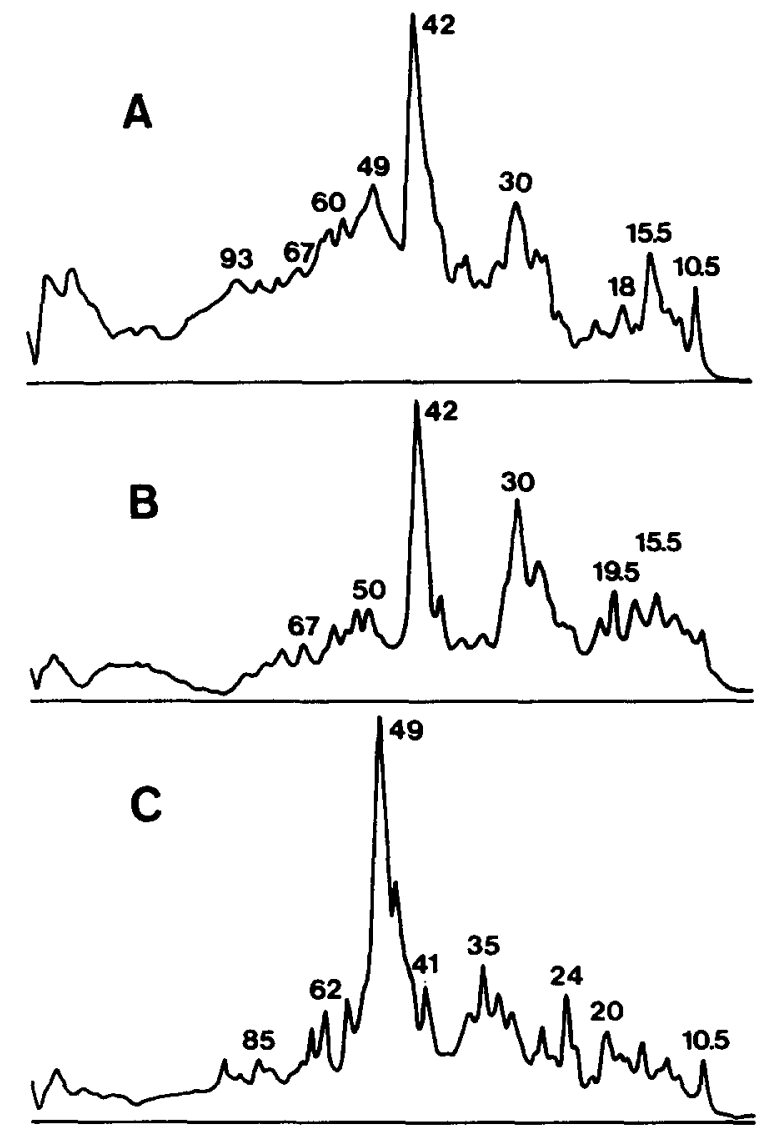

Fig. 6. Electrophoregrams (SDS gels) of, A: proteins extracted from spermatozoa by $\mathrm{Na}$ desoxycholate; $\mathrm{B}$ : proteins extracted from membrane vesicles obtained in band 2 after centrifugation of spermatozoa disrupted by nitrogen cavitation onto sucrose density gradients; $\mathrm{C}$ : proteins present in flagella after demembranation of spermatozoa by $\mathrm{Na}$ desoxycholate.

bers of protein bands were recognized by the antiserum for $\mathrm{NaCl}$-soluble sperm proteins. At least protein bands 42 and 49 to 70 (Fig. 5) were detected in fluids collected in the middle of the spermiation period. At the beginning and the end of this period, additional protein bands were recognized: $15.5,17$, $18,27,28,30,35,39,45,48$ and around $130 \mathrm{KD}$. Immunological crossreactivity of seminal fluid proteins (individual samples) with the antiserum for $\mathrm{NaCl}$-soluble sperm proteins was also checked by rocket immunoelectrophoresis. Six to a dozen rockets were observed depending on the samples. The height of the tallest rocket was roughly proportional to the total protein concentration in the sample and was unrelated to the relative amount of protein 42
KD (0 to $13 \%$ ). The $19 \mathrm{KD}$ seminal fluid protein was never recognized by any of the 3 antisera.

\section{HPLC fractionation of serum and seminal fluid proteins}

A total of respectively 11 peaks and 9 peaks were detected after fractionation of blood serum and seminal fluid proteins. The seminal protein peaks co-eluted with serum peaks but their heights were different. Electrophoretic analyses indicated that most of the major proteins common to the fluids and which have the same molecular weight were eluted by the same $\mathrm{NaCl}$ molarities.

\section{Proteins of sperm plasma membrane and flagella}

Most of the proteins extracted from spermatozoa by sodium desoxycholate had molecular weights ranging between 10.5 and $110 \mathrm{KD}$ (Fig. 6). The predominating protein was $42 \mathrm{KD}$ large.

Proteins present in the three bands obtained after membrane isolation using nitrogen cavitation and fractionation on sucrose gradient, were similar to those obtained using desoxycholate. However 48-110 KD proteins were present in lower amounts and there was few proteins between 32 and $40 \mathrm{KD}$ (Fig. 6). This suggests that in desoxycholate extracts all these proteins corresponded partly to detergent-soluble non-membranous (cytoplasmic?) proteins.

Among the flagellar proteins, one ( $49 \mathrm{KD}$ ) predominated. It most likely corresponded to the $\alpha$ and $\beta$ chains of tubulin. The other numerous protein bands were scattered between 10.5 and $120 \mathrm{KD}$. Major protein bands were $20,24,35,47,56$ and 62-70 KD.

Most of the saline-soluble proteins of spermatozoa (Fig. 2) co-migrated with membrane proteins and with some of the major flagellar proteins (Figs. 2 and 6). After transfer of saline-soluble proteins to nitrocellulose sheets, protein bands $14.5,29,45$ and 63-80 KD were commonly recognized by both antisera for seminal proteins and for serum proteins. Protein bands 30 and $42 \mathrm{KD}$ were detected only by antiserum for seminal proteins. 


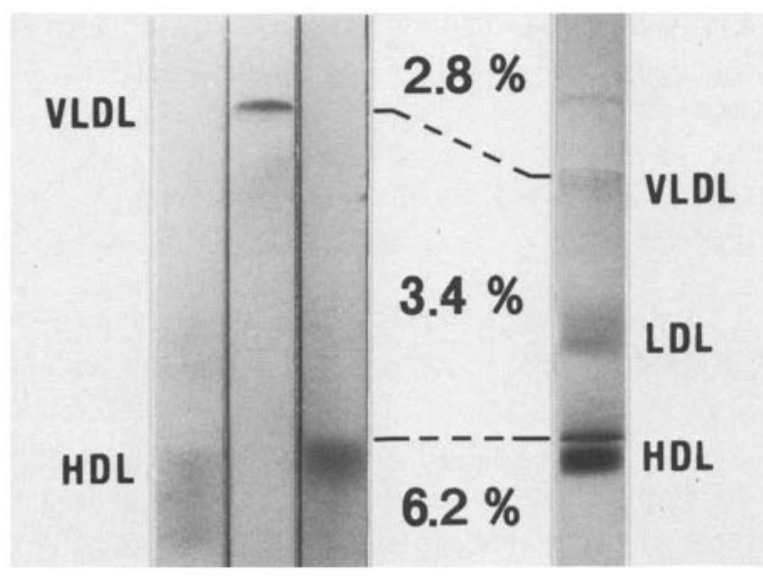

Fig. 7. Electrophoresis of trout lipoproteins in polyacrylamide step gradient gels $(2.8,3.4$ and $6.2 \%$ acrylamide $)$. 1: pool of seminal fluid; males in mid-spermiation period. 2: serum VLDL; same animals. 3: lipoproteins isolated from a pool of seminal fluid; males in mid-spermiation period. 4: serum total lipoproteins. Gels $1-3$ and gel 4 were not run together.

\section{Lipoproteins of seminal fluid}

When lipoproteins isolated from pools of seminal fluid were analysed by electrophoresis in discontinuous three-step gradient gels, lipoproteins were observed only in the $6.2 \%$ gel where they comigrated with serum HDL (Fig. 7).

When they were analysed on SDS gels, 2 protein bands were observed at 29 and $14.5 \mathrm{KD}$, the latter one being predominant. They co-migrated with AIlike and AII-like apoproteins present in serum HDL and LDL (Fig. 8). In addition, minor bands $12-14,54$ and $76 \mathrm{KD}$ were either present or absent depending on the pool of fluid. No detectable amounts of 29 and $14.5 \mathrm{KD}$ proteins remained in the bottom of the tubes after centrifugation of seminal fluid to isolate lipoproteins.

We determined protein $(P)$, total cholesterol $(C)$, triglyceride (T) and phospholipid (PL) in lipoproteins isolated from 9 pools ( 7 to 17 males) of seminal fluid collected weekly during the spermiation period. The mean lipoprotein concentration was $32.9 \pm 9.5 \mu \mathrm{g} / \mathrm{ml}$ seminal fluid (mean \pm SEM). The mean distribution of protein and lipid components as percentage of total lipoprotein weight was P: $50 \pm 6.3 \%, \mathrm{C}: 20 \pm 4.2 \%, \mathrm{~T}: 13 \pm 2 \%$ and PL: $17 \pm 3.5 \%$. The ratio $\mathrm{C} / \mathrm{P}(\mathrm{w} / \mathrm{w})$ was equal to

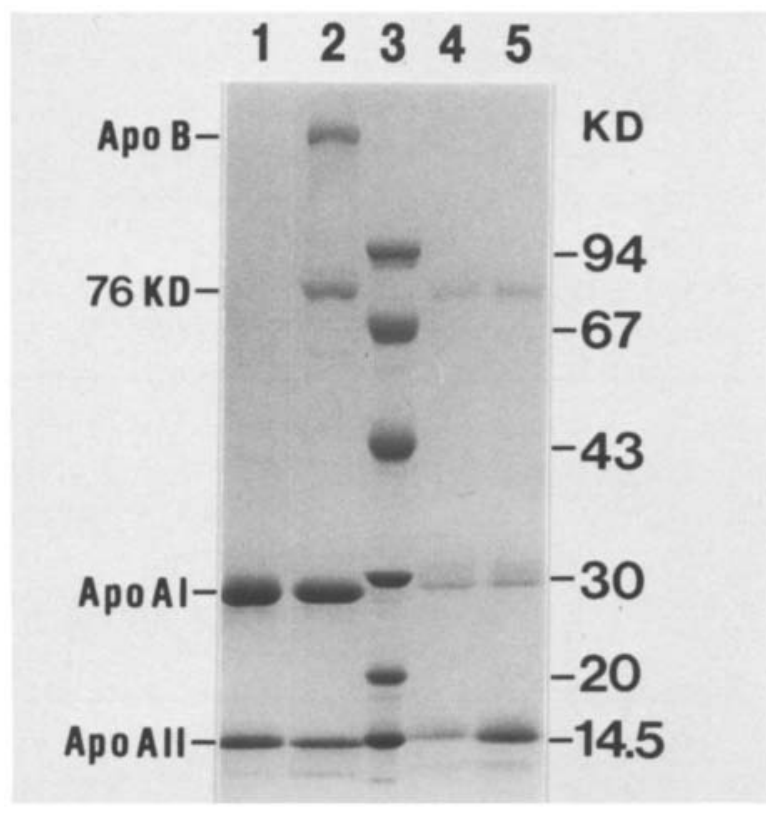

Fig. 8. Electrophoretic patterns (SDS-polyacrylamide gels) of trout apolipoproteins. 1: serum HDL. 2: serum LDL. 4 and 5: 2 pools of seminal fluid. 3: standard molecular weights.

$0.41 \pm 0.13$ and the ratio $\mathrm{T} / \mathrm{P}(\mathrm{w} / \mathrm{w})$ to $0.28 \pm$ 0.07 .

\section{Discussion}

In the rainbow trout, the protein concentration in seminal fluid is about 20 times lower than in blood serum (mean value in mature males of rainbow trout: $33 \mathrm{mg} / \mathrm{ml}$ according to Borchard 1978 and 36 to $41 \mathrm{mg} / \mathrm{ml}$ ( $\mathrm{n}=3$ pools) in our experiment). In mammals, protein levels in rete testis fluid are about 100 times less than in plasma (Setchell and Wallace 1972).

Our immunological data obtained in denaturing and non-denaturing conditions indicate that a lot of seminal proteins are antigenically-related to serum proteins. These are $11,14.5,16.5,29,34,40,45$ and 50 to $80 \mathrm{KD}$ proteins. After HPLC, each protein of both origin was eluted using the same $\mathrm{NaCl}$ molarity. These data suggest the presence in the 2 biological fluids of homologous proteins. Matsubara et al. (1985) have concluded that, in chum salmon, a number of serum proteins are present in 
the coelomic fluid, this suggesting that coelomic fluid could be derived at least in part from blood. In mammals, proteins present in rete testis fluid are also similar to serum proteins. However, even if some of them are derived from the passage of proteins from blood and lymph, it has been demonstrated that several serum-like proteins are produced by Sertoli cells (Mather et al. 1983). In the case of the trout seminal fluid, no data are available regarding the possibility of testis cells and/or cells lining the sperm duct producing some of the serumlike proteins. Immunological studies will permit the presence of such proteins in intralobular tests cells as well as in Sertoli cell culture medium to be identified.

Seminal proteins, present in variable relative amounts or even absent, depending on the samples, were recognized by the immuneserum for spermatozoa proteins. Among these recognized proteins, the following were not recognized by the immuneserum for serum proteins: $15.5,17,18,27,28$, $30,35,39,42$ and $49 \mathrm{KD}$. In addition, these proteins co-migrated with constantly present major membranous or flagellar sperm proteins. They are present, sometimes in conspicuous amounts, in seminal fluids collected, in particular, at the end of the spermiation period. These data suggest that they are proteins of spermatozoan origin which were released into the fluid by dying gametes. This assumption is corroborated by the observation of Maisse et al. (1988) and of Malejac et al. (1990) that the trout ejaculates which have the best fertility after cryopreservation contain spermatozoa with a high functional integrity of the plasma membrane and lack $42 \mathrm{KD}$ protein in the seminal fluid.

Other seminal proteins recognized by the immuneserum for saline-soluble sperm proteins comigrated with sperm proteins, which themselves were recognized by both immunesera for serum proteins and for seminal proteins. These are $\mathbf{4 5}$ and $63-80 \mathrm{KD}$ proteins. This could be due to the simultaneous presence in these bands, identified in 1D gels, of 2 proteins: one serum-like, the other one of spermatozoan origin. As an alternative explanation, these proteins may be serum-like seminal proteins which were bound to the sperm cells used to immunise the rabbits. This hypothesis is favoured by the fact that the 14.5 and $29 \mathrm{KD}$ saline-soluble sperm proteins were also recognized by the immuneserum for serum proteins. Thus, we propose that some of the major serum-like seminal proteins are present on the spermatozoa. Spermatozoa that were used were washed twice with SFMM after removal of the seminal fluid. Because such a washing treatment is perhaps not sufficient to remove proteins absorbed onto the gamete surface, we do not know whether these proteins were incorporated in the plasma membrane or only adsorbed. However, it may be noted that 48 to $61 \mathrm{KD}$ seminal proteins were not detected on the spermatozoa. This suggests that not all serum-like seminal proteins interact with the gamete membrane. Such interactions have been documented in mammals (Jones $e t$ al. 1983; Dacheux et al. 1989) as participating in the changes which occur in the protein composition of the sperm membrane during epididymal transit. In the trout, it is questionable whether, during sperm storage in the sperm duct, interactions between seminal proteins and the gamete membrane could be important to maintain the fertility of gametes.

Finally, only one major seminal protein was not characterized for its type or origin. It is the $19 \mathrm{KD}$ protein. It co-migrates with a protein present in trout coelomic fluid (data not shown), it differs from the coelomic fluid-specific protein identified by Matsubara et al. (1985) and it is questionable whether it is a gonad-specific protein.

Our data show that small amounts of HDL-like lipoproteins are present in trout seminal fluid. Lipids were detected in seminal fluid in cyprinid species (Belova 1982; Plouidy and Billard 1982), in the catfish Clarias gariepinus (Steyn and van Vuren 1986) and in Salmo salar (Piironen 1985), but not in Onchorhynchus keta (Morisawa et al. 1979). The presence of lipoproteins in seminal fluid has been suggested in mammals (Clavert et al. 1980), but only demonstrated in cockerels (Blesbois and Hermier, unpublished data). In trout as in cockerels, only HDL (or VHDL) have been identified. While in mature males of trout there is $10.13 \mathrm{mg} \mathrm{HDL} / \mathrm{ml}$ serum (Fremont and Marion 1982), there is a mean of $33 \mu \mathrm{g}$ HDL-like lipoproteins/ml seminal fluid, i.e., 160 times less than in serum. However, because we have determined phospholipid levels by an en- 
zymatic method which underestimates values compared to phospholipid phosphorus determination, the actual HDL concentration may be around 40 $\mu \mathrm{g} / \mathrm{ml}$. It is lower than that found for total lipids (around $200 \mu \mathrm{g} / \mathrm{ml}$ as a mean) in seminal plasma of Salmo salar (Piironen 1985), but it is only twice lower than in cockerels $(66 \mu \mathrm{g} / \mathrm{ml})$. These seminal HDL-like lipoproteins have a higher buoyant density $(1.27 \mathrm{~g} / \mathrm{ml})$ than the serum HDL $(1.21 \mathrm{~g} / \mathrm{ml}$; Fremont and Marion 1982). This disagrees with the fact that there is a trend for the $T / P$ and $C / P$ ratios to be slightly higher in seminal HDL than in serum HDL (respectively, $0.28 v s .0 .21$ and $0.41 v s$. 0.30 ).

In biological fluids, lipoproteins act as lipid carriers and HDL are the main vehicles for biomembrane lipid components (phospholipid and cholesteryl ester). Thus, we propose as a hypothesis, that the HDL-like lipoproteins present in seminal fluid interact with the sperm plasma membrane to maintain its lipid composition during storage in the sperm duct. This proposal is partly sustained by the observation that apo AI (29 KD) and apo AII (14.5 KD) were observed to be bound to spermatozoa.

At the present time, the possible origin of the various seminal HDL components is unknown. Although apo AI and AII were recovered in the humen of pieces of sperm ducts which were extensively washed then incubated for $24 \mathrm{~h}$, the 2 extremities being closed, we were unable to label these proteins with 14C-amino acids added to the medium surrounding the pieces of sperm ducts (unpublished data).

\section{Acknowledgements}

This work was supported in part by a grant from the Institut National de la Recherche Agronomique (GCS-BBA, 1988). We are grateful to Mrs C. Depays and to $F$. LeCornet for their assistance in lipoprotein preparation, to J.Y. Lefeuvre for excellent assistance in preparing the figures and to $\mathrm{J}$. Hall for help with the English.

\section{References cited}

Belova, N.V. 1982. Ecological and physiological properties of the semen of pond cyprinids. III. Physiological-biochemical parameters of the semen of some cyprinid species. J. Ichthyol. 22: $63-80$.

Billard, R. 1976. Variation de la qualité des gamètes a différents niveaux du tractus génital chez la truite arc-en-ciel. Ann. Hydrobiol. 7: 97-104.

Billard, R. 1983. Effects of coelomic and seminal fluids and various saline diluents on the fertilizing ability of spermatozoa in the rainbow trout, Salmo gairdneri. J. Reprod. Fert. 68: 77-84.

Billard, R, and Jalabert, B. 1974. L'insémination artificielle de la truite (Salmo gairdneri Richardson). II. Comparaison des effets des différents dilueurs sur la conservation de la fertilité des gamètes avant et après insémination. Ann. Biol. Anim. Bioch. Biophys. 14: 601-610.

Billard, R., Jalabert, B. and Breton, B. 1971. La production spermatogénétique chez la truite. Ann. Biol. Anim. Bioch. Biophys. 11: 199-212.

Billard, R. and Menezo, Y. 1984. The amino acid composition of rainbow trout (Salmo gairdneri) seminal fluid and blood plasma: a comparison with carp (Cyprinus carpio). Aquaculture 41: 255-258.

Billard, R., Dupont, J. and Barnabe, G. 1977. Diminution de la motilité et de la durée de conservation du sperme de Dicentrarchus labrax (poisson téléostéen) pendant la période de spermiation. Aquaculture 11: 363-367.

Borchard, B. 1978. Studies on the rainbow trout (Salmo gairdneri Rich.). I. Correlation between gonadal development and serum protein pattern. Ann. Biol. Anim. Bioch. Biophys. 18: 1027-1034.

Cheng, C.Y., Mather, J.P., Byer, A.L. and Bardin, C.W. 1986. Identification of hormonally responsive proteins in primary Sertoli cell culture medium by anion-exchange high performance liquid chromatography. Endocrinology 118: 480-488.

Clavert, A., Montagnon, E. and Brun, B. 1980. Studies on the origin and nature of seminal proteins by cellulose acetate electrophoresis. Androl. 12: 338-344.

Clemens, H.P. and Grant, F.B. 1964. Gonadal hydration of carp (Cyprinus carpio) and goldfish (Carassius auratus) after injections of pituitary extracts. Zoologica 49: 193-210.

Dacheux, J.L., Dacheux, F. and Paquignon, M. 1989. Changes in sperm surface membrane and luminal protein fluid content during epididymal transit in the boar. Biol. Reprod. 40: 635-651.

Fremont, L. and Marion, D. 1982. A comparison of the lipoprotein profiles in male trout (Salmo gairdneri) before maturity and during spermiation. Comp. Biochem. Physiol. 73B: $849-855$.

Johnston, A. and Thorpe, R. 1982. Immunochemistry in Practice. Blackwell Scientific Publications, Oxford.

Jones, R., Glos, K.I.V. and Brown, C.R. 1983. Changes in the protein composition of rat spermatozoa during maturation in the epididymis. J. Reprod. Fert. 67: 299-306. 
Klint, M., Sege, K., Curman, B., Ploen, L. and Peterson, P.A. 1985. Solubilisation and enrichment of boar sperm membrane proteins. Gamete Res. 11: 335-348.

Laemmli, U.K. 1970. Cleavage of structural proteins during the assembly of the head of bacteriophage $T_{4}$. Nature, Lond. 227: 680-685.

Leger, C., Fremont, L., Bergot, P. and Flanzy, J. 1979. Quelques recherches sur la digestion, l'absorption, le transport et le stockage des lipides chez le poisson. Interet d'une biochimie comparee des lipides. Med. Nut. 15: 61-71.

Lowry, O.H., Rosebrough, N.J., Farr, A.L. and Randall, R.J. 1951. Protein measurement with the Folin phenol reagent. J. Biol. Chem. 193: 265-275.

Maisse, G., Pinson, A. and Loir, M. 1988. Caractérisation de l'aptitude à la congélation du sperme de truite arc-en-ciel (Salmo gairdneri) par des critéres physico-chimiques. Aquat. Living Res. 1: 45-51.

Malejac, M.L., Loir, M. and Maisse, G. 1990. Qualité de la membrane des spermatozoides de truite arc-en-ciel (Oncorhynchus mykiss). Relation a velc l'aptitude du sperme à la congélation. Aquat. Living Res. 3: 43-54.

Mather, J.P., Gunsalus, G.L., Musto, N.A., Cheng, C.Y., Parvinen, M., Wright, W., Perez-Infante, V., Margioris, A., Liota, A., Becker, R., Krieger, D.T. and Bardin, C.W. 1983. The hormonal and cellular control of Sertoli cell secretion. J. Steroid Biochem. 19: 41-51.
Matsubara, T., Hara, A. and Takano, K. 1985. Immunochemical identification and purification of coelomic fluid-specific protein in chum salmon (Oncorhynchus keta). Comp. Biochem. Physiol. 81B: 309-314.

Morisawa, M. 1985. Initiation mechanism of sperm motility at spawning in teleosts. Zool. Science 2: 605-615.

Morisawa, M., Hirano, T. and Suzuki, K. 1979. Changes in blood and seminal plasma composition of the mature salmon Oncorhynchus keta during adaptation to freshwater. Comp. Biochem. Physiol. 64: 325-329.

Piironen, J. 1985. Variations in the properties of milt from the finnish landlocked salmon (Salmo salar $M$. sebago Girard) during a spawning season. Aquaculture 48: 337-350.

Plouidy, M.G. and Billard, R. 1982. The chemical composition of the companion fluids of the gametes in the common carp (Cyprinus carpio). In: Proc. Int. Symp. Reproductive Physiol. Fish. pp. 134. Edited by C.J.J. Richter and H.J.T. Goos. Pudoc, Wageningen.

Setchell, B.P. and Wallace, A.L.C. 1972. The penetration of iodine-labeled follicle-stimulating hormone and albumin into the seminiferous tubules of the sheep and rats. J. Endocrinol. 54: $67-77$.

Steyn, G.J. and van Vuren, J.H.J. 1986. The role of the bloodtestis barrier in the chemical composition of the seminal plasma of the freshwater teleost Clarias gariepinus. Comp. Biochem. Physiol. 83A: 421-425. 